\title{
Organic Geochemical Evaluation and Depositional Environment of Oil Sand from Mbano, SE Nigeria
}

\author{
M.U. Uzoegbu* ${ }^{1}$, N.R. Nwachukwu ${ }^{2}$ and O. Wosu ${ }^{2}$ \\ ${ }^{I}$ Michael Okpara University of Agriculture, Umudike, Abia State, Nigeria \\ ${ }^{2}$ University of Port Harcourt, Port Harcourt, Rivers State, Nigeria
}

\begin{abstract}
In this study, organic geochemical characteristics and depositional environment of the CretaceousTertiary aged oil sand deposits in Mbano Southeast Nigeria have been examined. Oil sands in all the studied areas are typically characterized by high hydrogen index and low oxygen index values. The organic richness of the oil sand, the quality, source and thermal maturity of organic matter discovered at Umuezeala Nsu (MBA) and Umualumaku $(M B B)$ in Mbano were determined on 13 oil sand samples. The results generally suggest relatively high Total organic matter content (TOC) for MBA and MBB oil sand samples ranging from 17.07 to $61.31 \mathrm{wt} \%$ with a mean of $44.43 \mathrm{wt} \%$ for MBA and from 29.55 to $52.94 \mathrm{wt} \%$ with a mean of $36.05 \mathrm{wt} \%$ for MBB respectively. This serves as a link in determining the quality of source rocks. The free hydrocarbon (S1) versus TOC plot was used to differentiate between allochthonous and autochthonous hydrocarbon. Tmax ranges from $412-431^{\circ} \mathrm{C}$ with mean value of $421.8^{\circ} \mathrm{C}$. Hydrogen index (HI) versus Tmax plot confirms that a significant amount of the organic matter is of lacustrine with a mixed marine and terrestrial origin. The HI of MBA and $M B B$ ranges from 771 to $869 \mathrm{mgHCg}^{-1} \mathrm{TOC}$ and 689 to $890 \mathrm{mgHCg}^{-1} \mathrm{TOC}$ respectively indicating the presence of type I kerogen. The Tmax versus Production index (PI) shows that MBA and MBB organic matter as immature but the Production index (PI) ranges from 0.16 and 0.29 indicating that the organic matters in MBA and $M B B$ have reached the production stage. The GC-MS results derived by CPI varies from 0.01 to 3.80 in $M B A$ and 0.14 to 0.90 in $M B B$ showing that MBA attended higher level of maturation as compared to MBB. Furthermore, indicated that MBA organic matter was deposited in a deeper environment than MBB or closer to heat source. Pr/Ph ratio (0.44-2.33; 0.68-3.55), Long/Short ratio (0.17-1.28; 0.10-0.66), OEP (0.40-1.22; 0.310.93), Pr/n- $C_{17}$ (0.10-2.10; 077-3.27), Ph/n- $C_{18}(0.04-3.50 ; 0.43-1.72)$ and $C_{31} /\left(C_{31}+C_{29}\right)$ (1.00-3.60) revealed the organic matter depositional environment as dysoxic to marine environment.
\end{abstract}

Keywords: Oil sand, TOC, Tmax, production Index, depositional environment, Anambra Basin, Nigeria.

\section{Introduction}

The studied area lies within latitudes $4^{\circ} 45^{\prime} \mathrm{N}$ and $7^{\circ} 15^{\prime} \mathrm{N}$, and longitude $6^{\circ} 50^{\prime} \mathrm{E}$ and $7^{\circ} 25^{\prime} \mathrm{E}$ with an area of around 5,100 sq km (Figure 1) and is within the Anambra basin.Oil sand is a naturally occurring mixture of sand, clay or other minerals, water and bitumen, which is heavy and extremely viscous oil that must be treated before it can be used by refineries to produce usable fuels such as gasoline and diesel. Oil sand which is also referred to as tar sand (Bituminous sand) has a similar composition as the light crude. It is believed to have been formed from biodegradation and water washing of light crude due to lack of cap rock (Akinyemi et al., 2013). Bitumen is about $20 \%$ of the actual oil sands found in Nigeria while $76 \%$ is for mineral matter that includes clay and sand and 4\% water (Akinyemi et al., 2013). The recovery process includes extraction and separation systems to remove the bitumen from the sand and water. The oil sand history started with the development of oil sand separation in the 1920s by Dr. Karl Clark. In 1936 Max Ball developed a way to produce diesel oil from oil sand (Nate, 2008). Nate (2008) also reported that the actual commercial production started in 1963 when the Sun Oil Company - later Suncor - started the construction of the first commercial oil sand production plant. The first barrel of commercial production by open pit mining was produced in 1967 (Syncrude, 2003).

Various countries of the world have embraced the exploration of oil sands as an alternate source of energy. In the Anambra basin, Southeastern Nigeria, oil sand deposits has been discovered in Mbano, Imo State. This study aims to determine the organic matter richness, quality, type, source, maturity variation, the geochemical characterization and depositional environment of the organic matter from the oil sand deposits. 


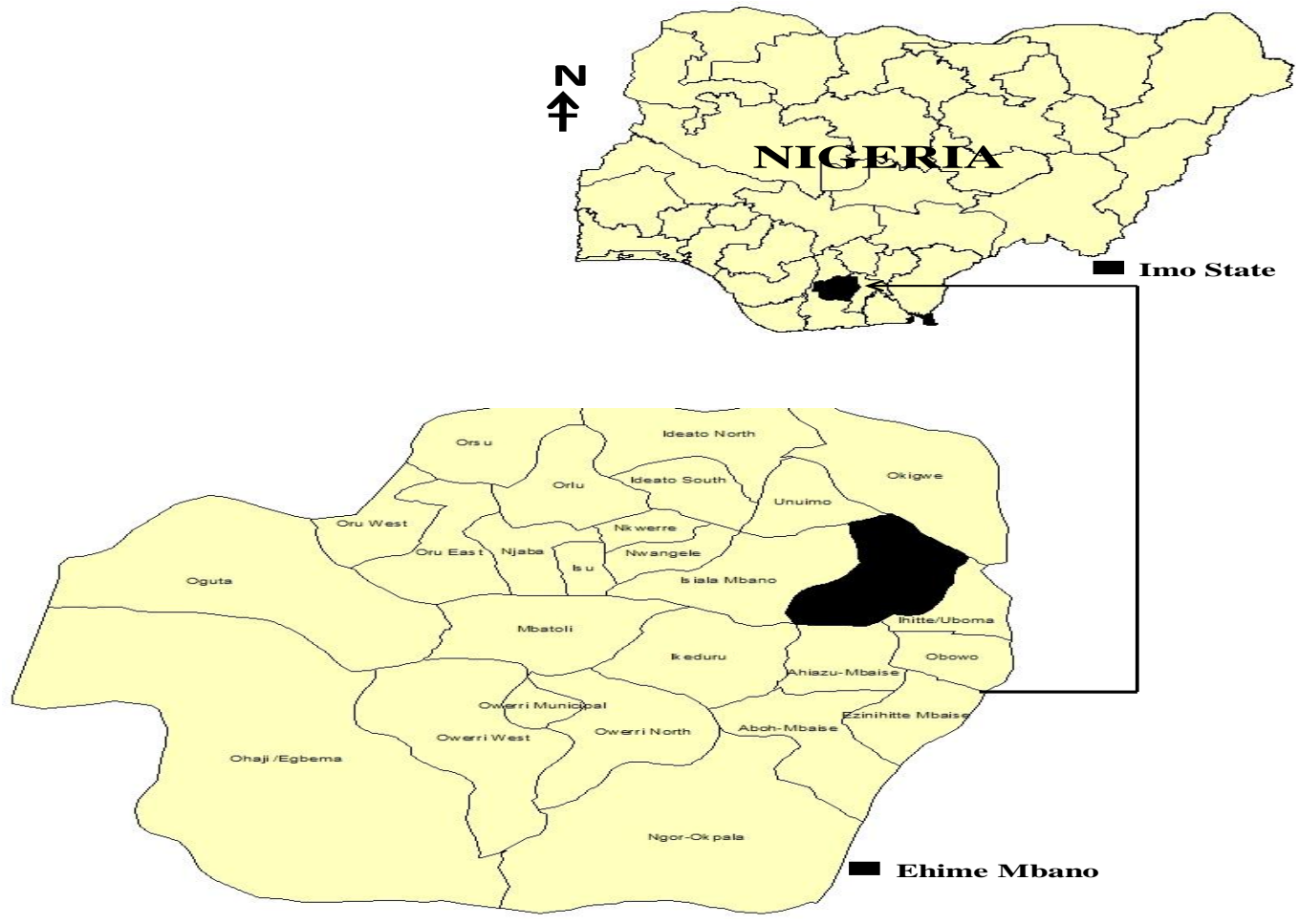

Fig. 1: Physiographic map of Imo State showing the Local Government Areas (inset: map of Nigeria showing the location of Imo State).

Nigeria has the largest oil sands/bitumen resources in Africa and is one of the top countries in the world in terms of its significant deposit potential (Meyer et al., 2007). Geological studies (Adedimila, 1987) and physicochemical properties (Ukwuoma, 1999) confirmed that Nigerian bitumen is an important source of energy and an alternative source of hydrocarbon and raw material for the petrochemical industries. Oil sands, tar sands or, more technically, bituminous sands, are a type of unconventional petroleum deposit. Oil sands are either loose sands or partially consolidated sandstone containing a naturally occurring mixture of sand, clay, and water, saturated with a dense and extremely viscous form of petroleum technically referred to as bitumen (or colloquially tar due to its similar appearance, odour, and colour). Oil produced from oil sands is often referred to as unconventional oil or crude bitumen, to distinguish it from liquid hydrocarbons produced from traditional oil wells. Solid bituminous sand (Oil sand) is formed in a number of ways. These include thermal attraction, microbial degradation, water washing or gas de-asphalting of the fluidly hydrocarbon. In Southwestern Nigeria, within the Dahomey basin, oil sand deposits has been found and localities studied include Idiobiolayo (Akinmosin and Shoyemi, 2010), Agbabu (Amigun et al., 2012), Imeri (Akinmosin et al., 2011), Idiopopo (Odunaike et al., 2010), Onikitibi (Akinmosin et al., 2012), and Imobi (Ikhane et al., 2011). The study of oil sand deposits in Nigeria is important so as to provide enough information for the exploration industries and also to enable Nigeria utilize maximally its unconventional oil deposits.

\section{Stratigraphic Setting}

The Studied area, Mbano lies within Anambra Basin in the Lower Benue Trough, (Reyment, 1965; Short and Stauble, 1967) and have the following lithostratigraphic divisions (Figure 2):

Sedimentation was restricted to the Calabar area before the regression and thermo-tectonic event that occurred during the Santonian times. According to many workers, this thermo-tectonics is related to the initiation of the formation of the Afikpo Basin and Anambra Basin. All Pre- Santonian beds were folded, faulted and uplifted to form the Okigwe-Abakaliki Anticlinorium trending NE-SW.

Murat (1972) Identified three major structural cycles in Southeastern Nigeria:

- The Aptian-Early Santonian, related to the initial rifting of the southern Nigerian continental region and opening of the Benue Trough. This phase produced two principal sets of faults trending NE-SW and NWSE. The NE-SW set of faults 


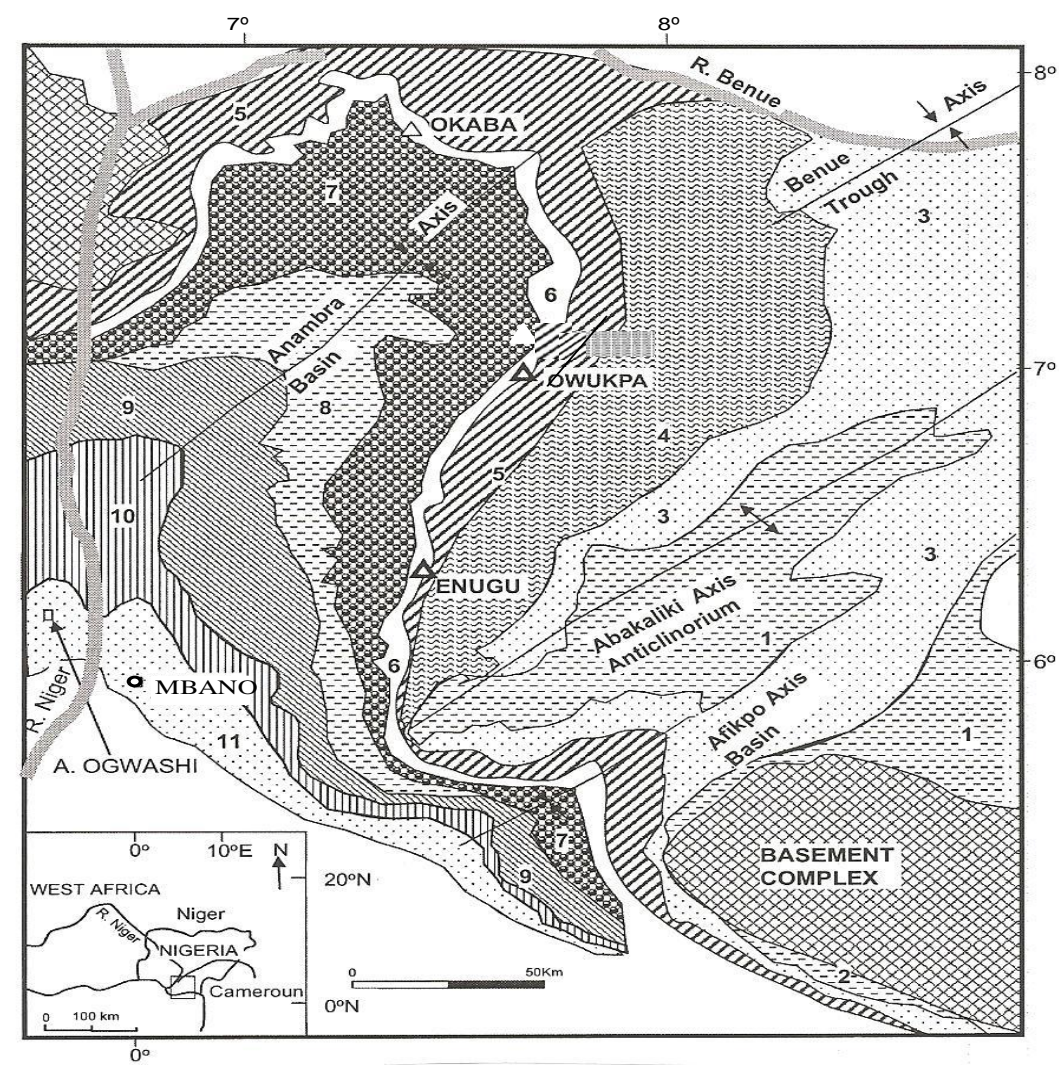

Fig. 2: Generalised geological map of the SE Nigeria (small circle area of inset) showing the location of the oil sand deposits. Numbers indicate Cretaceous and Tertiary formations shown in Fig. 7 as follows: 1. Asu River Group; 2. Odikpani Formation; 3. Eze-Aku Shale; 4. Awgu Shale; 5. Enugu/Nkporo Shale; 6. Mamu Formation;

7. Ajali Sandstone; 8. Nsukka Formation; 9. Imo Shale; 10. Ameki Formation and 11. Ogwashi-Asaba Formation (modified from Akande et al., 2007).

bound the Benue Trough, while the NW-SE deformed sedimentary beds within the Calabar Flank.

- The Turonian-Santonian, which was characterized by compressional movements resulting in the folding of the Abakaliki Anticlinorim and the development of the complementary Afikpo Syncline.

- The Late Campanian-Middle Miocene phase, which produced rapid subsidence and uplift in alternation with subsequent progradation of a delta.

During the Coniacian, beds of rapid changing lithofacies including shale, limestone and an increasing amount of sandstone were deposited in South- Eastern Nigerian. The rapid facies change has been interpreted by (Short and Stauble, 1967) as being the first indication of onset of active tectonic phase of folding, faulting and upliftment which ended during Santonian. These Santonian movements resulted in the folding and upliftment of the NE striking Abakaliki Anticlinorium which in turn led to the exposure and subsequent erosion of the Coniacian, Turonian and Albian Formations. Consequent to this uplift, two depressions were formed flanking the Abakaliki Anticlinorium; the wide Anambra Basin to the NW and the narrow Afikpo Syncline to the South East (Kogbe, 1976). These two depressions became the main foci of deposition during the Campanian to Palaeocene.

\section{Materials And Methods}

Two methods of sample collection were employed within this period. These are the grab and bulk sampling methods. Although the grab method of sampling is not the best for collection of samples for analysis, it was used here to get representative samples from Mbano for oil sand in order to carry out laboratory analyses on a large scale.Chisel, spatula and sample bags were used for the collection of the samples. The samples collected were labeled according to each locality. Care is taken to avoid sampling unwanted sections or contamination in the samples.

A total of 13 samples were collected from oil sand in two locations of Umuezeala Nsu (MBA) and Umualumaku (MBB). The number of samples from any of this locality was based on the accessibility of the sample area and the extent to which the oil sand is development at the outcrop (Plates A and B). 


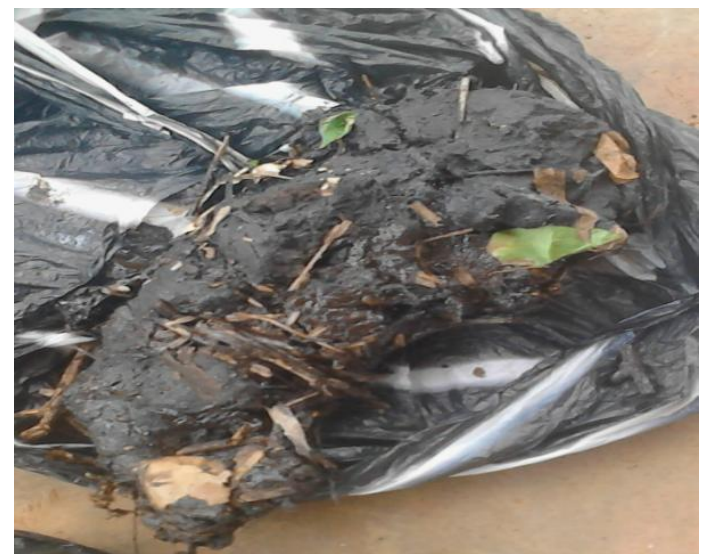

(a)

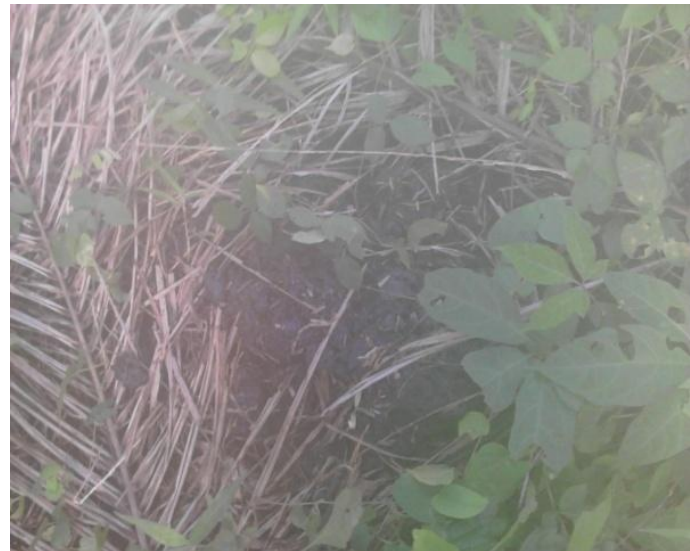

(b)

Plates: Field photograph of oil sand outcrops at Mbano; a). Umuezeala Nsu and b). Umualumaku localities. Magnifications X 50

\section{Samples Preparation}

A total of thirteen bulk oil sand samples were analysed. For each of these samples, 2 to $3 \mathrm{~g}$ was used for the analyses. The samples were dissolved on a temperature below $40^{\circ} \mathrm{C}$ to remove the dirts and sands on the samples. These dissolved samples were measured crucible ready for Rock-Eval analysis.

\section{Rock-Eval 6 Pyrolysis}

A total of thirteen samples from Mbano have been subjected to Rock-Eval pyrolysis.

The instrument used was the Rock-Eval 6 Classic $\mathrm{S}_{3}$ that has a programmed heat conducted from $100^{\circ} \mathrm{C}$ to $850^{\circ} \mathrm{C}$ for both the pyrolysis and the oxidation ovens. A mass of $2-3 \mathrm{mg}$ of dissolved oil sand samples were weighed in crucibles with a balance weighing instrument model Sartorius ISO 9001. The weighed samples together with the crucibles were placed in a Rock-Eval 6 machine where the samples were subjected to initial temperature of $100^{\circ} \mathrm{C}$ before it was increased to $300^{\circ} \mathrm{C}$ and finally to the temperature of $850^{\circ} \mathrm{C}$. In between these temperatures, the Tmax, the temperature at maximum rate of pyrolysable $\left(\mathrm{S}_{2}\right)$ hydrocarbon generation, was determined. Also free oil content $\left(\mathrm{S}_{1}\right)$, pyrolysable hydrocarbon content $\left(\mathrm{S}_{2}\right)$, and amount of $\mathrm{CO}_{2}\left(\mathrm{~S}_{3}\right)$ were determined (Figure 2).
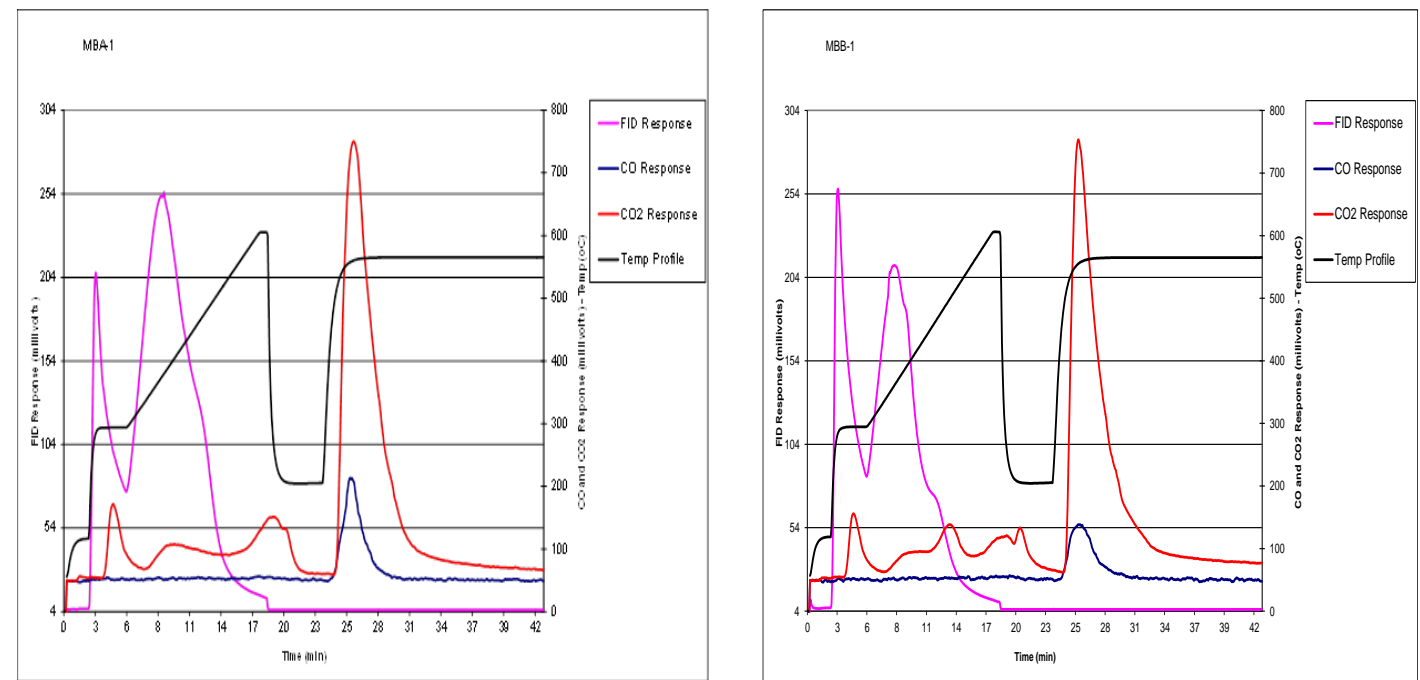

Fig. 3: Programmed pyrolysis result profile showing MBA and MBB samples.

During heating at temperatures between 100 to $300^{\circ} \mathrm{C}$ free hydrocarbon (S1) is obtained. As cracking of kerogen continued in the furnace at temperature between 400 and $600{ }^{\circ} \mathrm{C}$ residual hydrocarbons potential $\left(\mathrm{S}_{2}\right)$ is obtained. Increase in temperatures from 600 to $850{ }^{\circ} \mathrm{C}$ cause the liberation of $\mathrm{CO}_{2}$ resulting in the determination of $\mathrm{S}_{3}$. In between the temperatures of 400 to $600{ }^{\circ} \mathrm{C}$ maximum temperature (Tpeak) is attained leading to the birth line or determining the maturity of an individual sample. 


\section{GC-MS Analysis}

The oil sand ( $3 \mathrm{gm}$ ) were first dissolved in DCM (dichloromethane) (200mls) to remove the sand, clay which are insoluble in DCM, the solution was decimated separating the sand and clay out. The resultant solution was left in a fume chamber to evaporate, the tar was then dissolve in $200 \mathrm{mls}$ of pentane (AnalaR Grade) while stirring and continued for $1 \mathrm{hr}$. the solution was allowed to cool in a freezer for $2 \mathrm{hrs}$ at $5^{\circ} \mathrm{C}$. The precipitated asphaltene were filtered off washed with cold $\mathrm{n}$-pentane and dried in a dessicators, then weighed and scraped into a sample vials. The obtained asphaltene were then presented for GC-MS analysis for a suite of metals. The metals were mainly the biophiles (Udo et al., 1992). A $3 \mathrm{~g}$ of the sample (asphaltene) was subjected to sohxlett extraction using a solvent mixture of acetone, chloroform and methanol (47: $30: 23 \mathrm{v} / \mathrm{v})$ at $60^{\circ} \mathrm{C}$ for 24 hours to extract the soluble organic matter. The extract was concentrated by evaporation to dryness using a rotating vapour evaporator at $250 \mathrm{mb}$. The extract was transferred to an $8 \mathrm{ml}$ vial using the same solvent mixture and allowed to evaporate to dryness in a vented hood. The dried extract was fractionated by silica gel column chromatography with a column prepared using $2 \mathrm{~g}$ of baker silica gel calcined at $200^{\circ} \mathrm{C}$ for 24 hours to yield six fractions ranging from saturate to polar (Figure 4).

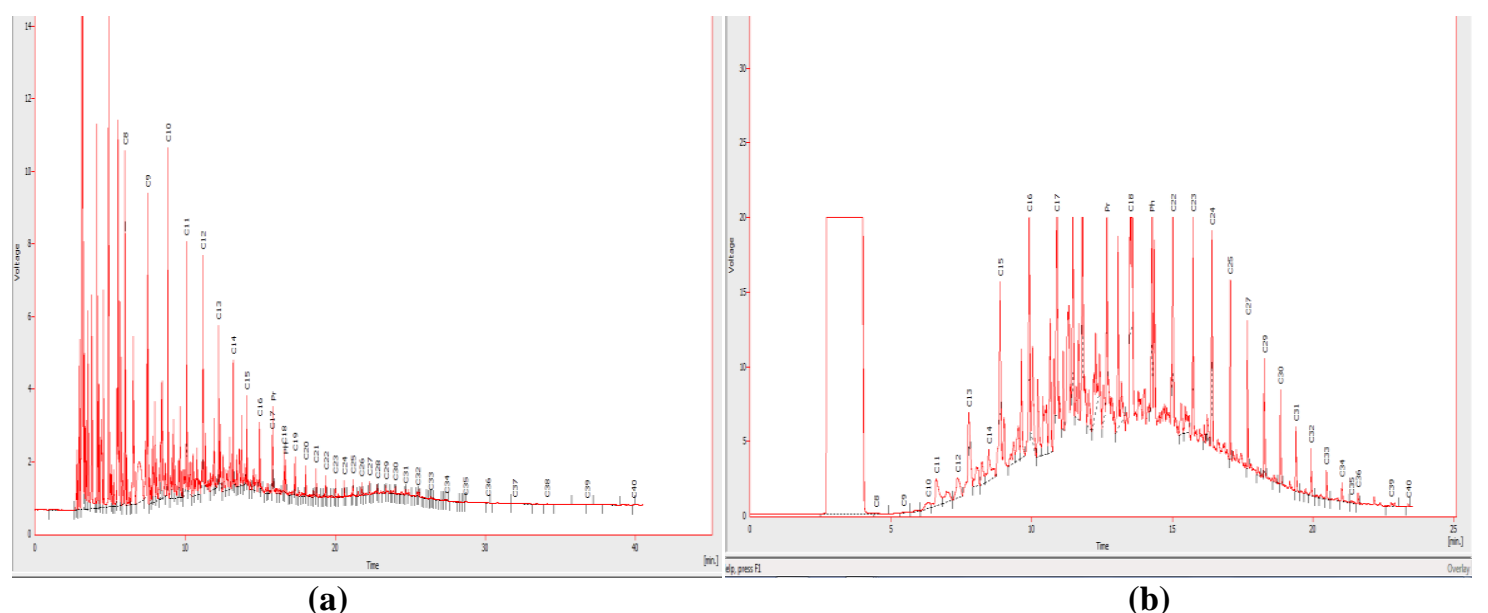

Fig. 4: Chromatogram finger print of oil sand samples from; a) Umuezeala Nsu (MBA) and b) Umualumaku (MBB).

The saturate fraction was subjected to urea adduction to separate isoprenoids from $n$-alkanes and subjected to gas chromatography-mass spectrometry (GC-MS) using a CE 5980 GC coupled to an HP Finnigan $8222 \mathrm{MS}$ held at $80^{\circ} \mathrm{C}$ for three minutes and raised to $310^{\circ} \mathrm{C}$ at $3^{\circ} \mathrm{C} \mathrm{min}{ }^{-1}$ and held isothermally for 10 minutes in order to assess some molecular parameters used in source rock characterization.

\section{Results And Discussion}

Organic matter (or organic material, natural organic matter) is matter composed of organic compounds that has come from the remains of organisms such as plants and animals and their waste products in the environment (Baker, 1972). Following the deposition of organic-rich sediments, microbial processes convert some of the organic matter into biogenic methane gas. Greater depths of burial are accompanied by increase in heat in accordance with the basin's geothermal gradient. This heat and diagenetic processes cause the organic matter to gradually transform into an insoluble organic matter know as kerogen.

The capacity to generate petroleum depends largely on the chemical composition of this convertible carbon fraction (Lebile kerogen). The TOC measurement is the first screen for quantifying organic richness. TOC values provide only a semi-quantitative scale of petroleum-generating potential. TOC indicates the quantity, but not the quality of organic matter. If this initial screening test demonstrates sufficient organic content, the rock should undergo additional tests to ascertain organic matter quality and maturity.The MBA TOC values range from 17.07 to $61.31 \mathrm{wt} \%$ with a mean of $44.43 \mathrm{wt} \%$. Tmax values for MBA Oil sand samples range from $412-431^{\circ} \mathrm{C}$ (Table 1). The MBB TOC values range from 29.55 to $52.94 \mathrm{wt} \%$ with a mean value of $36.05 \mathrm{wt} \%$. Tmax values for MBB oil sand samples ranges from $418-424^{\circ} \mathrm{C}$. The pyrograms of oil sand samples from MBA and MBB is shown in Figure 3.Total organic carbon (TOC) which is the measure of the amount of carbon found in an organic compound is important in the geochemical characterization of oil sands. $0.5 \mathrm{wt} \%$ of TOC is the minimum value and is considered as the minimum limit for hydrocarbon generation (Tissot and Welte, 1984; Bordenove et al., 1993; Hunt, 1996; Hendrix et al., 1995). The data obtained in Table 1 show that the total organic carbon content values for MBA oil sand samples are between 17.07 and 61.31. TOC content of MBA-5 is the lowest. These values indicate excellent oil sand samples. 
The TOC content for MBB 1-4 are between 27.04 and 52.94 with MBB-2 as the lowest. These also indicate excellent oil sand samples. This is confirmed by the plot of TOC (wt \%) versus S2 (Figures 5 and 6). On the other hand, the plot of S1 versus TOC (Figures 7 and 8) can be used to discriminate between non-indigenous hydrocarbon (allochthonous) and indigenous hydrocarbons (autochthonous). The plots show that the oil sand samples of MBA and MBB were characterized equally by allochthonous hydrocarbon and autochthonous hydrocarbon. This indicates that part of the oil migrated from another location. TOC is used here as a link to determine variation in source rock quality through expulsion of oil.

Hydrogen index (HI) MBA ranges from 771 to $869 \mathrm{mgHC} / \mathrm{gTOC}$ (Table 1) with an average of 799 mgHC/gTOC. The average HI from $\mathrm{S}_{2}$ vs. TOC plot (Langford and Blanc-Valleron, 1990) of oil sand samples from MBA is $799 \mathrm{mgHC} / \mathrm{gTOC}$ (Figure 5). HI vs. OI was plotted on modified Van Krevalen diagram for MBA Oil sand samples. The HI vs. OI plots for the samples plotted in the organic matter type I fields (Figure 9). Tmax vs. HI plot of MBA oil sand samples is shown on Figure $11 . \mathrm{S}_{2} / \mathrm{S}_{3}$ values range from 59.85 to 216.89 (Table 1). In Table 1, $\mathrm{S}_{1} / \mathrm{TOC}$ values are between 1.66 and 2.65. The production Index (PI) for MBA samples are between 0.16 and 0.27 . HI of MBB ranges from 689 to $890 \mathrm{mgHC} / \mathrm{gTOC}$ (Table 1) with an average of 744.5 $\mathrm{mgHC} / \mathrm{gTOC}$. The average HI from $\mathrm{S}_{2}$ vs. TOC plot (Langford and Blanc-Valleron, 1990) of oil sand samples from MBB is $744.5 \mathrm{mgHC} / \mathrm{gTOC}$ (Figure 6).

Table 1: Results of Rock-Eval analysis and calculated parameters.

\begin{tabular}{|c|c|c|c|c|c|c|c|c|c|c|c|}
\hline Sample Name & Lithology & $\begin{array}{c}\text { Tmax } \\
{ }^{\circ} \mathrm{C}\end{array}$ & $\begin{array}{c}\mathrm{S} 1 \\
(\mathrm{mg} / \mathrm{g})\end{array}$ & $\begin{array}{c}\mathrm{S} 2 \\
(\mathrm{mg} / \mathrm{g})\end{array}$ & $\begin{array}{c}\mathrm{S3} \\
(\mathrm{mg} / \mathrm{g})\end{array}$ & $\mathrm{PI}$ & $\mathrm{S} / \mathrm{s3}$ & S1/TOC & TOC\% & HI & OI \\
\hline \hline
\end{tabular}

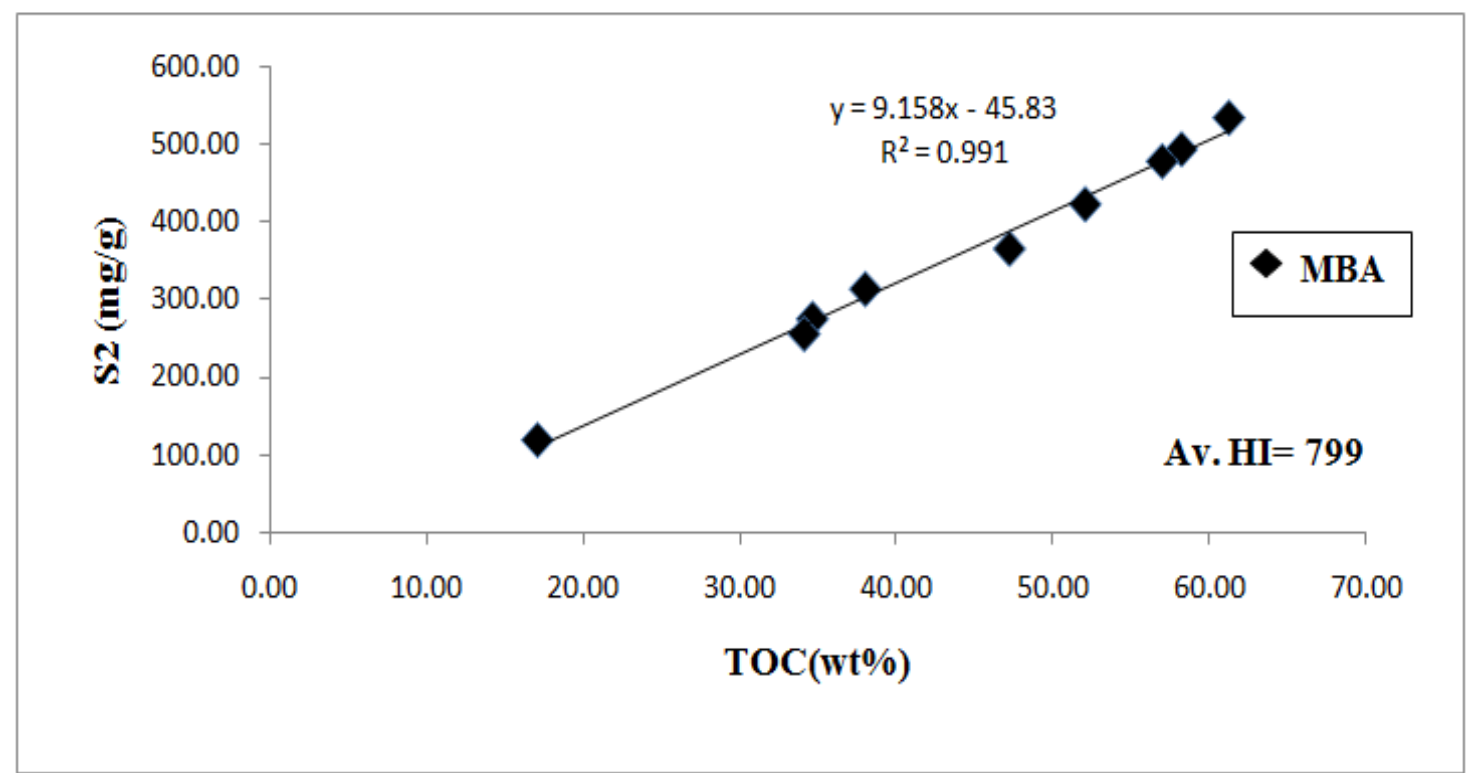

Fig. 5: S2 vs TOC plot of MBA oil sand samples with calculated average hydrogen index (Av. HI. Sample name attached). 


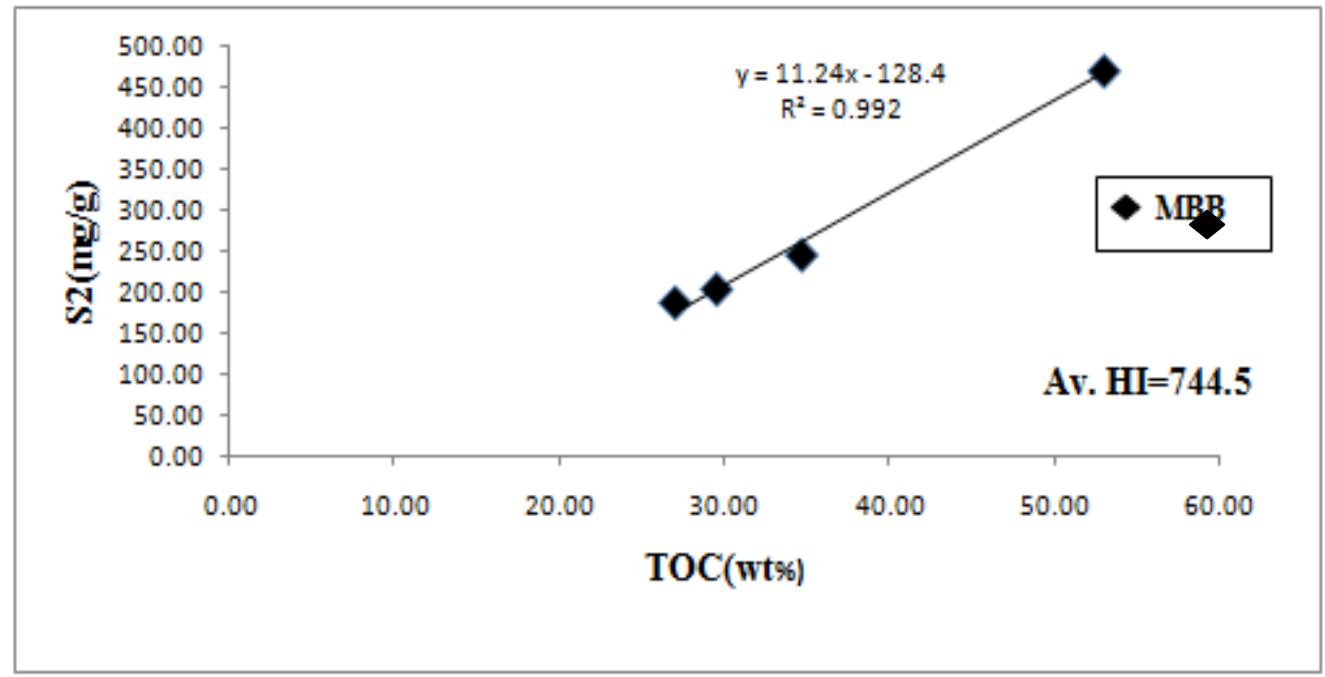

Fig. 6: S2 vs TOC plot of MBB oil sand samples with calculated average hydrogen index (Av. HI. Sample name attached).

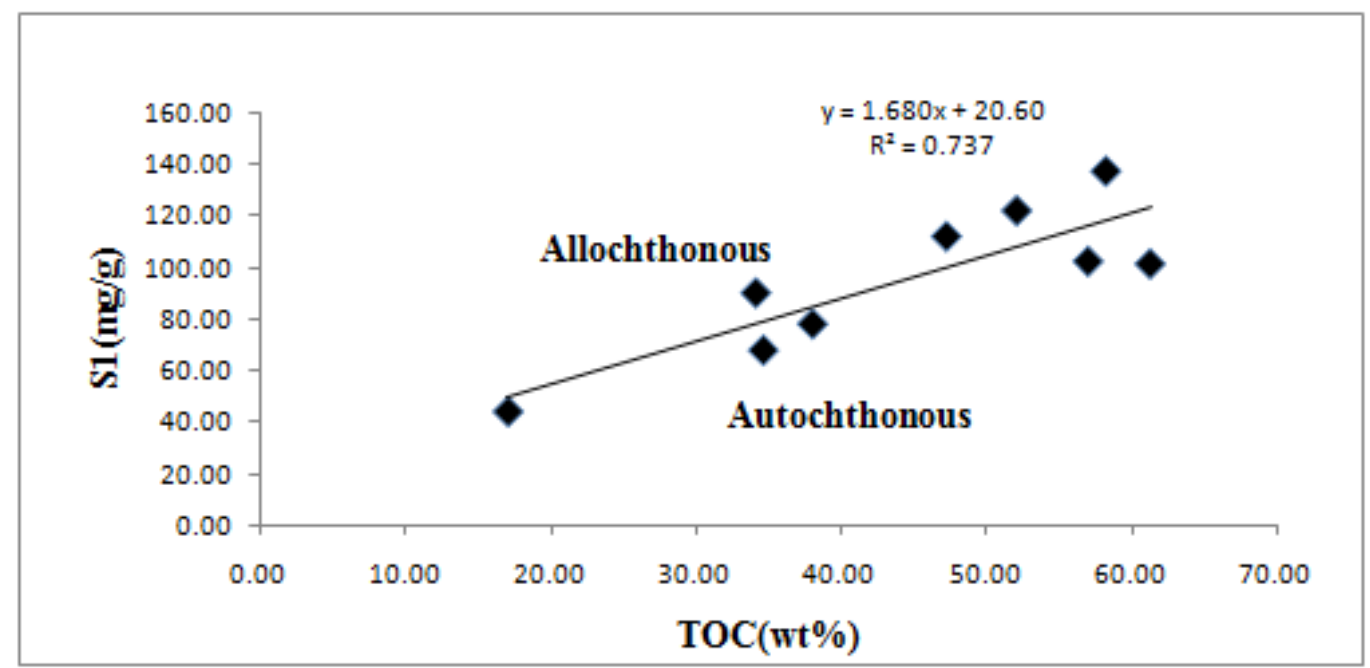

Fig. 7: Diagram of S1/TOC using MBA oil sand samples for discriminating between non indigenous and indigenous hydrocarbon.

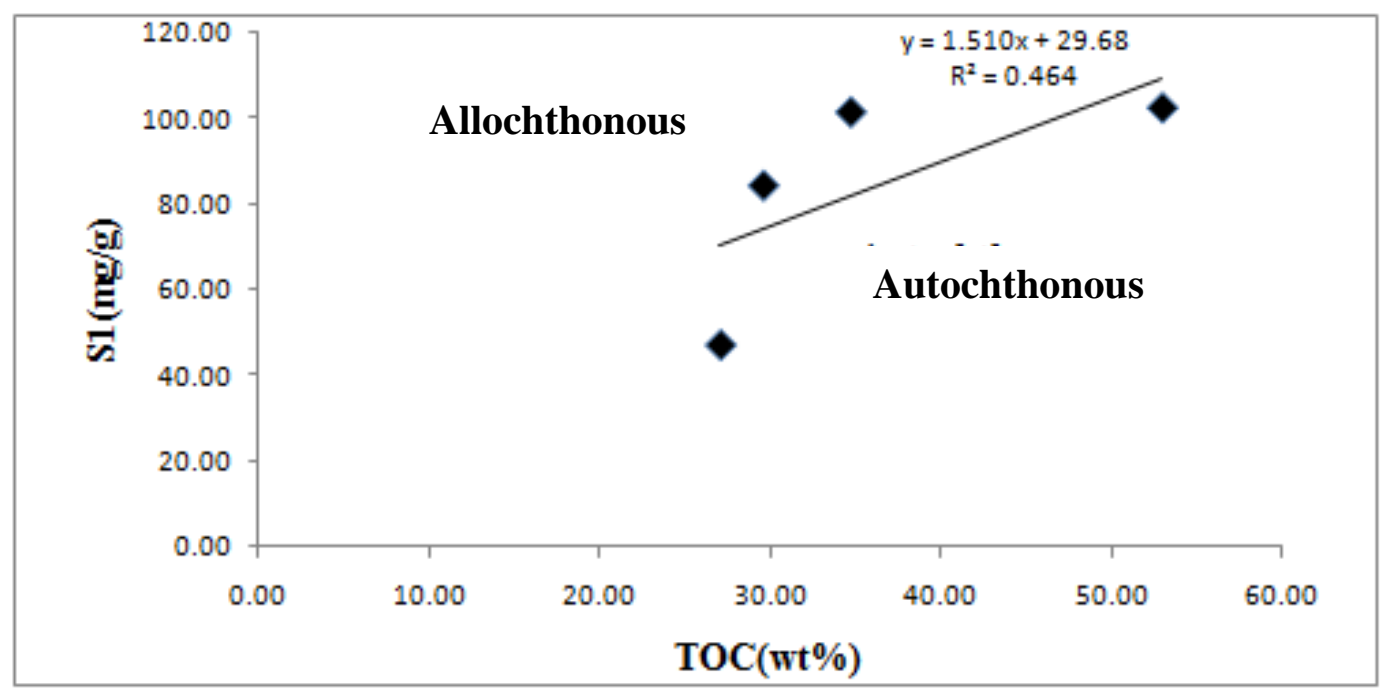

Fig. 8: Diagram of S1/TOC using MBB oil sand samples for discriminating between non indigenous and indigenous hydrocarbon. 


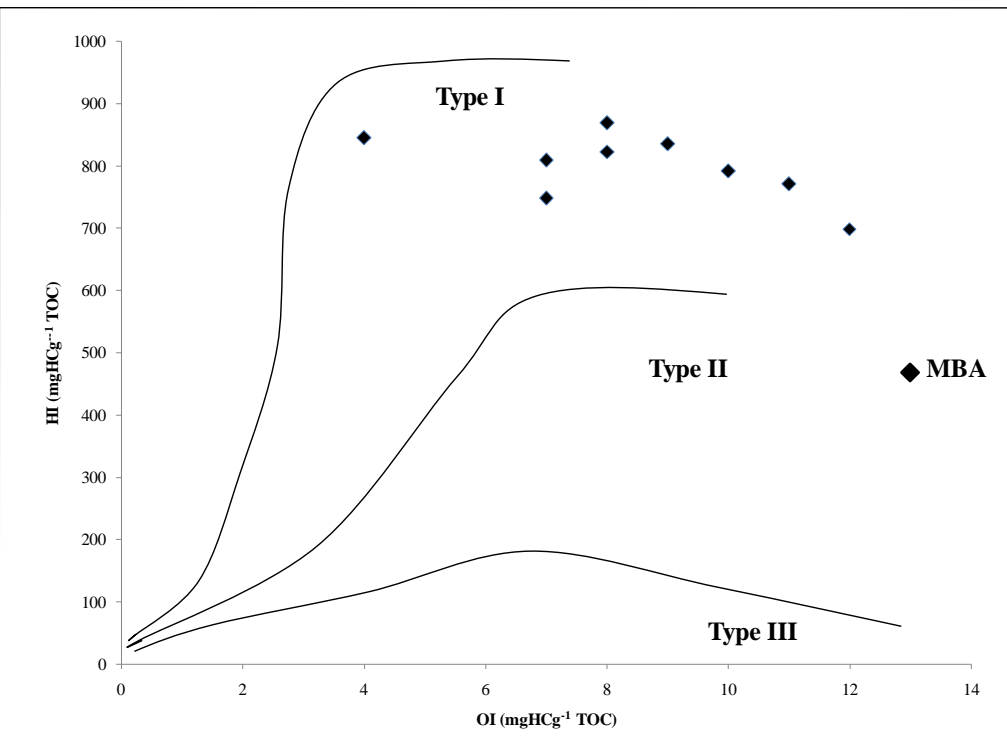

Fig. 9: HI vs. OI plot of oil sand samples from Umuezeala Nsu (MBA).

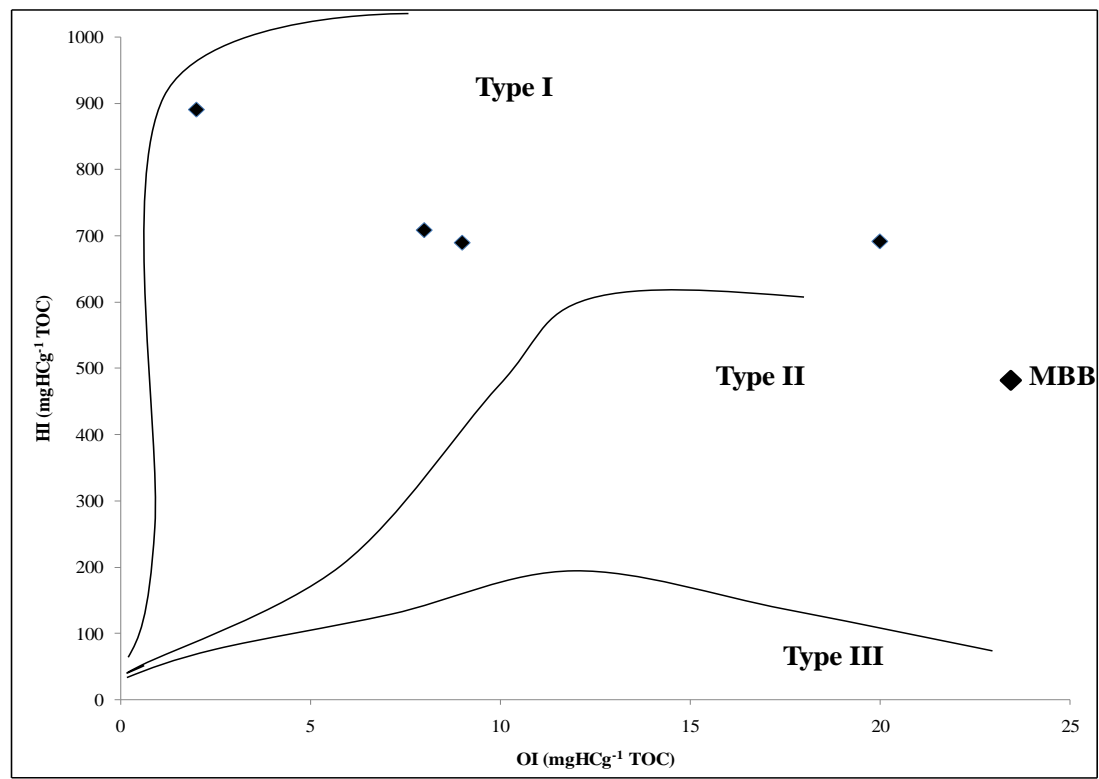

Fig. 10: HI vs. OI plot of oil sand samples from Umualumaku (MBB).

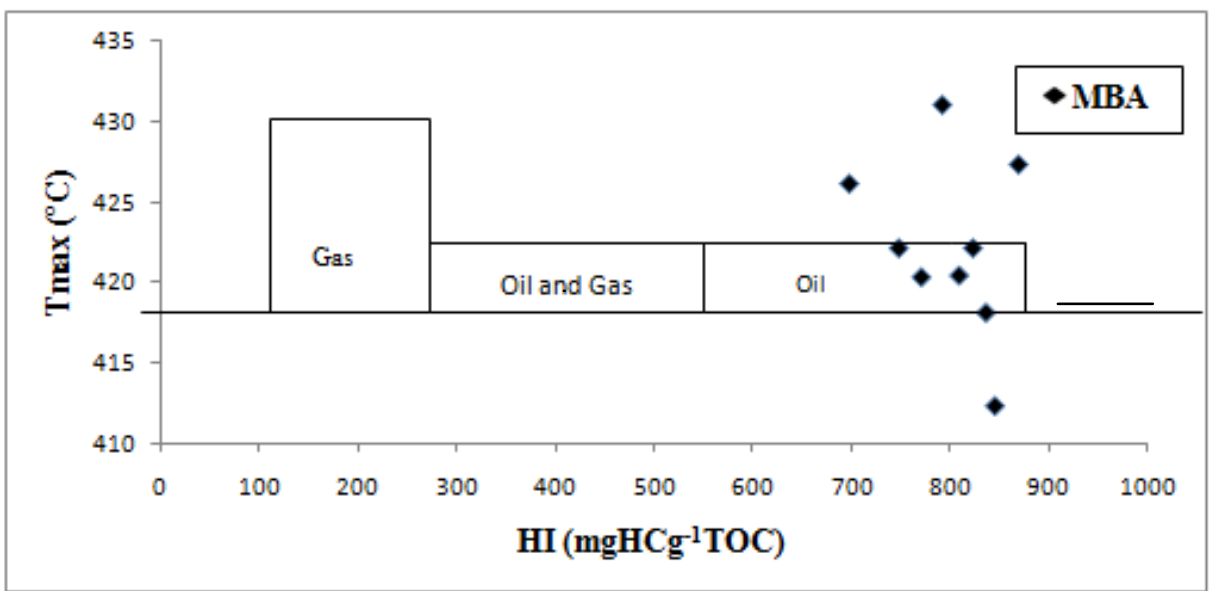

Fig. 11: Tmax vs HI plot of MBA Oil sand samples. 


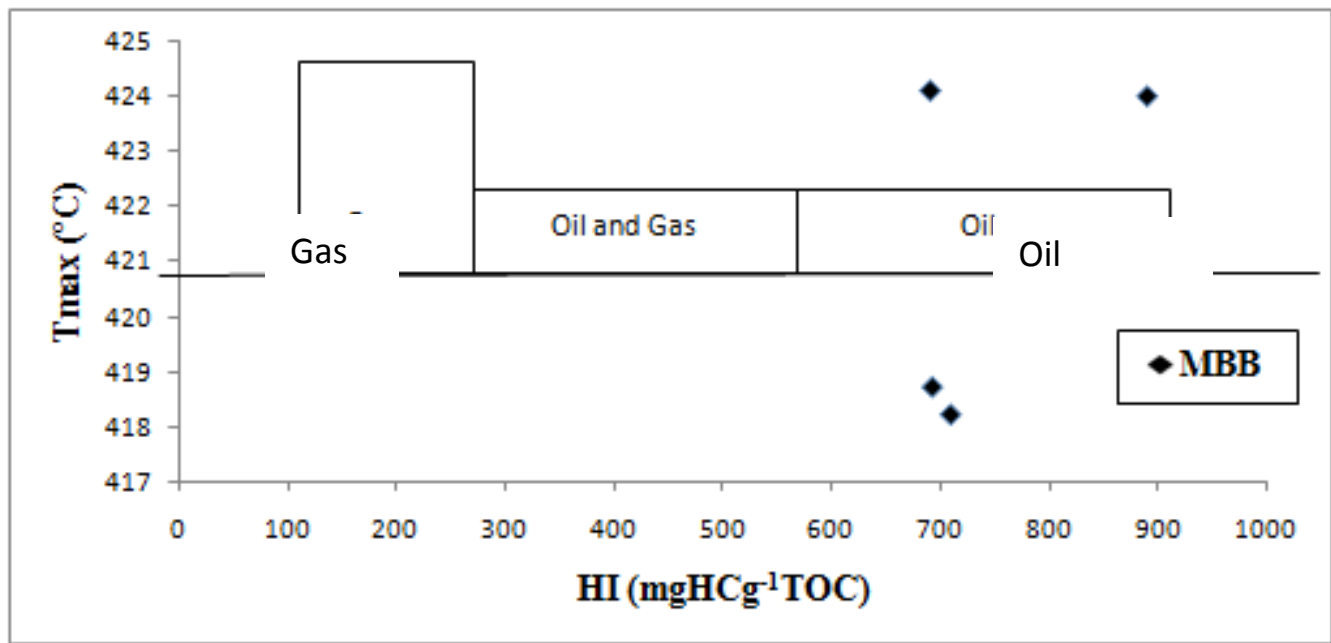

Fig. 12: Tmax vs HI plot of MBA Oil sand samples.

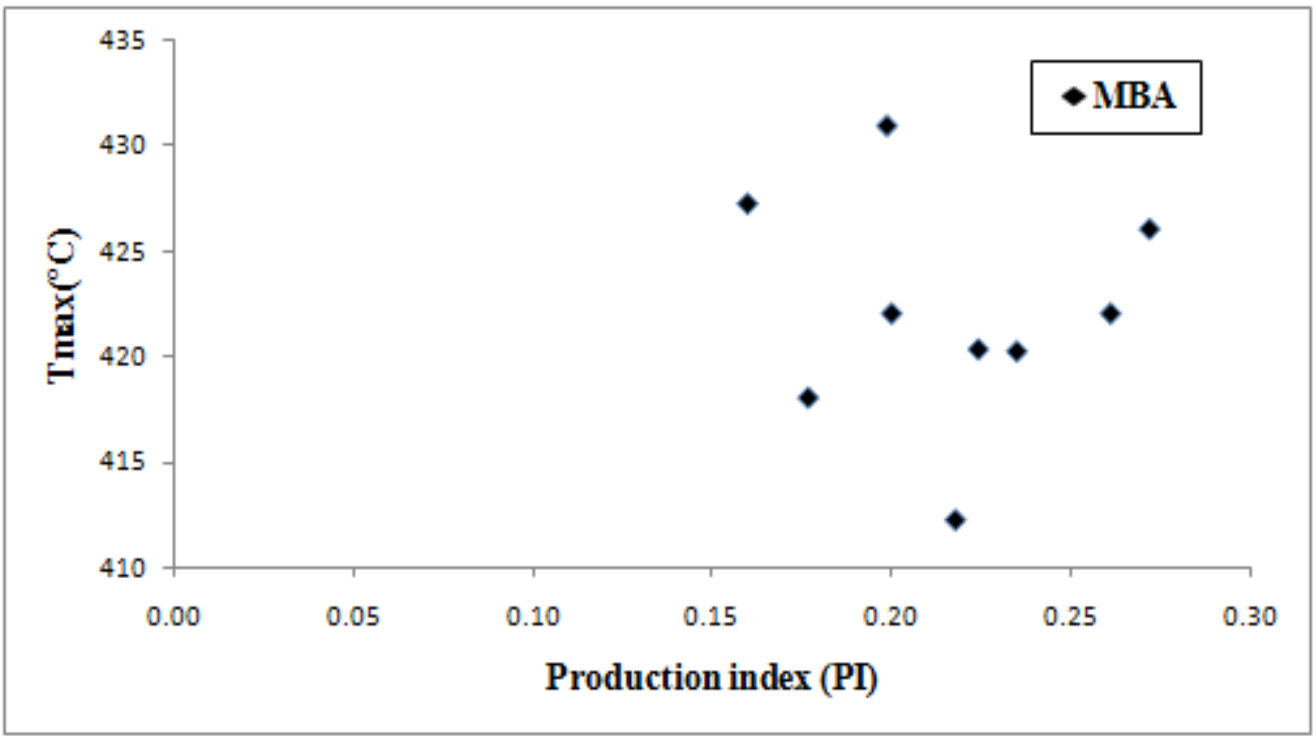

Fig. 13: Tmax vs. Production index plot of MBA oil sand samples.

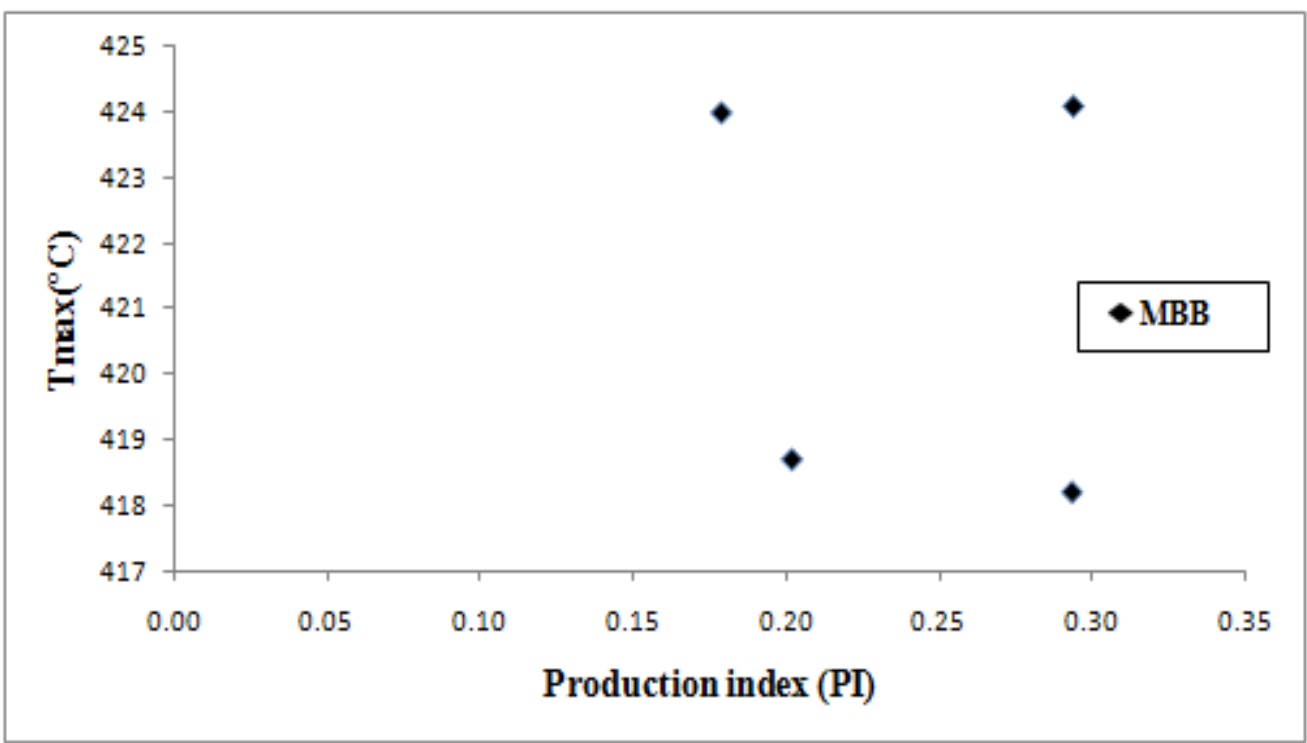

Fig. 14: Tmax vs. Production index plot of MBB oil sand samples. 
HI vs. OI was plotted on modified Van Krevalen diagram for MBB oil sand samples. The HI vs. OI plots for the samples plotted in the organic matter type I fields (Figure 10). Tmax vs. HI plot of MBB oil sand samples is shown on Figure 12. $\mathrm{S}_{2} / \mathrm{S}_{3}$ values range from 33.98 to 444.65 (Table 1). In Table $1, \mathrm{~S}_{1} /$ TOC values are between 1.75 and 2.94. The PI for MBB samples are between 0.18 and 0.29. The quality of organic matter $(\mathrm{OM})$ in the oil sand samples was done by using Rock-Eval generated data (HI and Tmax). The MBA and MBB oil sand samples plot mainly along the oil prone kerogen evolutionary pathway as indicated by the plot of $\mathrm{HI}$ against Tmax. This confirms that a substantial proportion of the OM is of marine origin with oil potential.

The type of kerogen in the oil sand samples determines its quality. Type I kerogen is the highest quality and type III is the lowest. Waples (1985) used the HI values to differentiate between the types of OM. HI <150 $\mathrm{mg} / \mathrm{g}$ indicates mainly type III kerogen (Gas prone), Hydrogen indices between 150 and $300 \mathrm{mg} / \mathrm{g}$ indicates that the $\mathrm{OM}$ is oil and gas prone but mainly gas because it contains more type III kerogen than type II kerogen. HI $>300 \mathrm{mg} / \mathrm{g}$ is oil and gas prone but mainly oil because it contains a large amount of type II kerogen than type III kerogen. Kerogen with HI $>600 \mathrm{mg} / \mathrm{g}$ indicates the presence of type I or type II kerogen and therefore have an excellent hydrocarbon potential (Oil prone). The HI values of MBA oil sand samples ranges from 771 and 869 indicating the presence of type I or type II kerogen while hydrogen index for MBB oil sand samples ranges from 689 and 890 also indicating the presence of type I or type II kerogen.

The plot of $S_{2}$ vs. TOC plot (Langford and Blanc-Valleron, 1990) in figs. 5 and 6 shows that the MBA samples are characterized by kerogen type I while the MBB oil samples are characterized by kerogen type I and type II. HI versus OI plot as carried out by Van Krevelen (1961), which is used to determine the kerogen type (Figures 9 and 10) shows that the MBA oil sand samples are generally plotted under type I kerogen, while the MBB oil sand samples are also plotted under type I kerogen. High HI content in this oil sand is probably caused by unusual kind of organism rich in lipids that formed the OM.

The Tmax values measured during the pyrolysis and the calculated PI values are closely related to thermal history of the OM (Tissot et al., 1984; Waples, 1985). According to Peters, 1986 and Espitalié et al., 1985, oil generation began at $\operatorname{Tmax} 435-465^{\circ} \mathrm{C}$, and PI between 0.2 and 0.4 , the $\mathrm{OM}$ are in immature stage when Tmax has a value less than $435^{\circ} \mathrm{C}$, and PI less than 0.2 and the gas generation began at Tmax $470{ }^{\circ} \mathrm{C}$, and production index PI more than 0.4. HI versus Tmax (Espitalié et al., 1985) plot (Figures 11 and 12) shows that the MBA and MBB oil sand samples plotted in the immature zone of type I kerogen. The plot of Tmax versus PI (Waples, 1985; Peters, 1986) (Figures 13 and 14) shows that the MBA and MBB oil sand samples are immature. PI results hovers between 0.16 and 0.29 indicating that the OM has reached the production stage. PI also allowed dissemination of oil when Tmax below threshold affects the OM. Again, Tmax is applied here to determine maturation variation of the $\mathrm{OM}$ of the source rock that produced the oil sands.

\section{Environmental Geochemistry}

Low Molecular Weight (LMW) n-alkanes are usually produced by marine biogenic sources while High Molecular Weight (HMW) n-alkanes are usually produced from terrestrial vascular plant. Concentrations of LMW and HMW n-alkanes can be obtained from the following:

$\mathrm{LMW}=$ Sum of concentrations of aliphatic hydrocarbons ranging from $\mathrm{nC}_{10}$ to $\mathrm{nC}_{20}$.

$\mathrm{HMW}=$ Sum of concentrations of aliphatic hydrocarbons range from $\mathrm{nC}_{21}$ to $\mathrm{nC}_{36}$.

Predominantly, lower molecular weight $n$-alkanes exist in fresh oil while higher plants, marine animals and sedimentary bacteria show higher molecular weight n-alkanes (Pingchang et al., 2013). Main peaks with carbon numbers greater than $\mathrm{nC}_{20}$ reflect the significant incorporation of higher plant wax and some fungi, whereas those with lower carbon numbers indicate major inputs from microbial activity (algae and bacteria $\mathrm{nC}_{17}, \mathrm{nC}_{18}$ ) or petroleum (diesel exhaust $-\mathrm{nC}_{20}, \mathrm{nC}_{21}$ ). LMW/HMW ratio in $\mathrm{n}$-alkanes in sediments is used to distinguish macrophytes from terrestrial plants (Pingchang et al., 2013). Values below 1 show natural input from terrestrial biogenic sources while values above 1 show natural input from marine biogenic sources. LMW is predominance in the sample locations.

Long Chain Hydrocarbons ( $\mathrm{LHC}$ ) is n-alkanes above $\mathrm{nC}_{20}$ while Short Chain Hydrocarbons $(\mathrm{SCH})$ is n-alkanes below $\mathrm{nC}_{20}$. $\mathrm{LHC} / \mathrm{SHC}$ ratio is used to assess the macrophyte/land plant and phytoplankton- dominant trends. Low LHC/SHC values such as 0.21 to 0.80 are dominantly phytoplankton derived. Intermediate values such as 2.38 to 4.33 show a mixture of both input sources. Higher ratios above 4.0 are dominated by terrestrial plant waxes (Pingchang et al., 2013). It is predominance of long chain over short chain n-alkanes as their values varies from 0.17-1.28 in MBA to 0.10-0.66 in MBB (Table 2) indicating a dominance source of marine organic matter (Guangyou et al., 2013).

The $\mathrm{Pr} / \mathrm{Ph}$ ratios from 0.44 to 3.55 in both locations suggest a marine to terrestrial derived material because $\mathrm{Pr} / \mathrm{Ph}$ is found mainly from the phytol portion of photosynthetic plant chlorophyll (Didyk et al., 1978; IIIich, 1983). Value of OEP varies from 0.31-0.93 in the oil sand from MBB-02 to 0.40-1.22 from MBA-03 (Table 2). 
These values of OEP for immature higher plant contributions are often $>1.0$ but approach 1.0 with increasing maturity (Bray and Evans, 1961; Didyk et al., 1978). The CPI results gotten from MBA and MBB could be said that majority of the terrestrial material is probably transported by fluvial processes and deposited under marginal to marine environments (Bird et al., 1995; Obaje et al., 2004) which contribute to the marine source of $\mathrm{OM}$ in the MBA and MBB samples.

Table 2: Showing n-Alkanes, Isoprenoids distribution and ratios from GC of oil sand samples from Mbano,

\begin{tabular}{|c|c|c|c|c|c|c|}
\hline $\begin{array}{l}\text { Sample } \\
\text { Name }\end{array}$ & Locality & Lithology & Basin & CPI & $\begin{array}{l}\mathrm{Pr} / \mathrm{Ph} \\
\text { Ratio }\end{array}$ & $\begin{array}{c}\text { Long/Shor } \\
\text { Ratio }\end{array}$ \\
\hline MBA-01 & Umuezeala & Oil Sand & Anambra & 2.19 & 1.87 & 0.33 \\
\hline MBA-02 & $"$ & $"$ & $"$ & 2.34 & 0.60 & 0.29 \\
\hline MBA-03 & $"$ & " & $"$ & 1.62 & * & 0.17 \\
\hline MBA-04 & $"$ & " & $"$ & 0.22 & 1.96 & 0.24 \\
\hline MBA-05 & $"$ & " & $"$ & 1.73 & 0.50 & 0.37 \\
\hline MBA-06 & $"$ & $"$ & $"$ & 3.80 & 2.33 & 0.39 \\
\hline MBA-07 & $"$ & " & $"$ & 0.10 & 0.55 & 0.39 \\
\hline MBA-08 & $"$ & $"$ & $"$ & 0.15 & 1.14 & 0.37 \\
\hline MBA-09 & $"$ & " & $"$ & 0.01 & 0.44 & 1.28 \\
\hline MBB-01 & Umualumaku & $"$ & $"$ & 0.90 & 3.55 & 0.10 \\
\hline MBB-02 & $"$ & " & $"$ & 0.16 & 1.13 & 0.26 \\
\hline MBB-03 & $"$ & " & $"$ & 0.19 & 0.68 & 0.66 \\
\hline \multirow[t]{2}{*}{ MBB-04 } & $"$ & $"$ & $"$ & 0.14 & 1.96 & 0.51 \\
\hline & & $\begin{array}{c}*=\text { Not } \\
\text { determine }\end{array}$ & & & & \\
\hline
\end{tabular}

$\begin{array}{cccc}\text { OEP } & \mathrm{Pr} / & \mathrm{Ph} / & \mathrm{C} 31 / \\ & \mathrm{n}-\mathrm{C} 17 & \mathrm{n}-\mathrm{C} 18 & (\mathrm{C} 31+\mathrm{C} 29) \\ 1.09 & 0.36 & 0.32 & 3.10 \\ 1.01 & 2.10 & 3.50 & 2.00 \\ 1.22 & 0.35 & \cdot & 2.10 \\ 0.56 & 0.98 & 0.38 & 1.00 \\ 0.95 & 0.33 & 0.43 & 2.60 \\ 0.96 & 0.10 & 0.04 & 3.60 \\ 0.40 & 0.48 & 0.59 & 1.00 \\ 0.44 & 0.77 & 1.69 & 1.00 \\ 0.51 & 1.44 & 2.74 & 1.00 \\ 0.93 & 2.23 & 0.79 & 1.40 \\ 0.31 & 0.77 & 0.43 & 1.00 \\ 0.39 & 2.38 & 1.72 & 1.00 \\ 0.35 & 3.27 & 0.65 & 1.00\end{array}$

The ratio $\mathrm{C}_{31} / \mathrm{C}_{31}+\mathrm{C}_{29}$ of these two n-alkanes $\left(\mathrm{C}_{31}\right.$ and $\left.\mathrm{C}_{29}\right)$ are higher in the sample numbers of MBA and MBB both in oil sand samples with values 3.60 and 1.40 (Table 2) respectively. The carbon preference index (CPI) of the n-alkanes also varies with values ranging from 0.14-0.90in the oil sand samples from MBB0.1 and 0.01-3.80 in the oil samples from MBA-02 (Table 2; Figure 4). This indicates more maturation of OM in $\mathrm{MBB}$ area than the MBA area or location MBB may be closer to higher heat source.

The CPI 25-33=0.5*[( $\left.\left.\mathrm{C}_{25}-\mathrm{C}_{33}\right) /\left(\mathrm{C}_{24}-\mathrm{C}_{32}\right)\right]+\left[\left(\mathrm{C}_{25}-\mathrm{C}_{33}\right) /\left(\mathrm{C}_{26}-\mathrm{C}_{34}\right)\right] \mathrm{n}$-alkanes can be derived from two sources i.e. vascular plant wax and fossil fuel combustion products (Ali et al., 2015). An odd carbon preference is characteristic of oils derived from source rocks deposited in non-marine environments. In contrast, the predominance of an even numbered n-alkane preference is commonly observed in bitumen and oils derived from carbonate or evaporate rocks. This is usually characterized with CPI values that are lower than 1 . If the total even and odd numbers of paraffin are equally abundant, the value of (CPI) will be equal to 1 as generally observed in high maturity samples. This shows that the hydrocarbons are petrogenic in origin.

Predominance of vascular plants input to the environment usually demonstrates CPI values from 1 to 3 (Ali et al., 2015). The average CPI value of 0.35 was obtained from MBB samples and 1.35 from samples of MBA suggesting marginal maturity. Although this parameter is usually low in marine source rock that produce mostly low molecular weight hydrocarbons (Cooles et al., 1986; Peters and Moldowan, 1993; Eseme et al., 2002; 2006; Sengüler et al., 2008). CPI in the $\mathrm{C}_{25}-\mathrm{C}_{31}$ range of samples from the Anambra Basin is generally high $(>1)$, indicating immaturity and reflecting the contribution of wax-derived n-alkanes which form bitumen at the end of diagenesis (Hunt, 1996).

$\mathrm{Pr} / \mathrm{C}_{17}$ values range from $0.10-2.10$ in the $\mathrm{MBA}$ sample and values from 0.77-3.27 in MBB while $\mathrm{Ph} / \mathrm{C}_{18}$ is between 0.04-3.50 in the MBA and 0.43-1.72 from MBB (Table 2; Figure 4) indicating marginal to marine depositional environment. The result of $\mathrm{C}_{31} /\left(\mathrm{C}_{31}+\mathrm{C}_{29}\right)$ (1.00-3.60) also supported values obtained for $\mathrm{Pr} / \mathrm{C}_{17}$ and $\mathrm{Ph} / \mathrm{C}_{18}$ depositional environment of the organic matter as dysoxic to marine environment (Pingchang et al., 2013).

\section{Acknowledgements}

Gratitude is expressed to all the Staff in the Departments of Geology, Michael Okpara University of Agriculture and University of Port Harcourt for their advice. Trican Geological Solutions, Alberta, Canada is gratefully acknowledged for the analyses of these samples.

\section{References}

[1]. Adedimila AS, (1987). Okitipupa bituminous sands: New construction materials for flexible pavements? Nig. Eng., $22,1-14$.

[2]. Akande SO, Ogunmoyero IB, Petersen HI, Nytoft HP, (2007). Source rock evaluation of coals from the Lower Maastrichtian Mamu Formation, SE Nigeria. Jour. Petrol.Geol., 30(4), 303-324.

[3]. Akinyemi LP, Odunaike RK, Fasunwon OO, (2013). Physical and chemical characterization of oil sands observed at Imeri in Ogun state of South Western Nigeria, CSPG/CSEG/CWLS GeoConvention Integration: Geoscience Engineering Partnership, 6-12 May, Calgary, Ab, Canada. 
[4]. Akinmosin AA, Shoyemi O, (2010). Technical Feasibility of direct application of the Nigerian Tar Sand Deposits as Road Asphalt. Pacific J. Sci. Techn., 11(1), pp. 526-536.

[5]. Akinmosin A, Omosanya KO, Folorunsho AF, Ariyo SO, Aiyeola SO, (2011). Structural Control for Bitumen Seepages in Imeri, Southwestern, Nigeria. Int. J. Basic and Applied Sci., 11(1), 93-103.

[6]. Akinmosin AA, Omosanya KO, Ikhane PR, Mosuro GO, Goodluck I, (2012). Characterisation of a bitumen seepage at Onikitibi, Eastern Dahomey Basin, SW, Nigeria. Adv. Applied Sci. Res., 3(4), 2078-2089.

[7]. Ali S, Arash, VM, Ya $\square$ mur K, Ay $\square$ e KY, (2015). Evaluation of the Hydrocarbon Potential, Mineral Matrix effect and Gas-Oil Ratio Potential of Oil Shale from the Kabalar Formation, Göynük, Turkey. Oil Shale, 32(1), 25-41.

[8]. Amigun JO, Adelusi AO, Ako BD, (2012). The application of integrated geophysical methods in oil sand exploration in Agbabu area of Southwestern Nigeria. Int. Res. J. Geol. Mining (IRJGM), 2(9), 243-253.

[9]. Baker DR, (1972). Organic Geochemistry and Geological Interpretation. J. Geol.

[10]. Edu., 20, 221-234.

[11]. Bird MI, Summons RE, Gagan MK, Roksandic Z, Dowling L, Head J, Fifield LK, Cresswell RG, Johnson DP, (1995). Terrestrial vegetation change inferred from n-alkanes $13 \mathrm{C}$ analysis in the marine environment: Geochem. Cosmochim. Acta., 59, 2853-2857.

[12]. Bordenove ML, Espitalie J, Leplat P, Oudin JL, Vandenbrouke M, (1993). Screening techniques for source rock evaluation. In: Bardenave, M.L. (ed.), Appl. Petrol. Geochem, Paris Eds. Technip., 217-278.

[13]. Bray EE, Evans ED, (1961). Distribution of n- paraffins as a clue to recognition of source beds. Geochem. Cosmochim. Acta, 22, 215.

[14]. Cooles GP, Mackenzie AS, Quigley TM, (1986). Calculation of petroleum masses generated and expelled from source rocks. Org. Geochem., 10, 235-245.

[15]. Didyk BM, Simoneit BRT, Brassell SC, Eglinton G, (1978). Organic geochemical indicators of paleodepositional conditions of sedimentation: Nature, 272, 216-222.

[16]. Eseme E, Agyingi CM, Foba-Tedo J, (2002). Geochemistry of brine emanations from Cretaceous strata of the Mamfe Basin, Cameroon. J. Afri. Earth Sci., 35(4), 467-476.

[17]. Eseme E, Littke R, Agyingi CM, (2006). Geochemical characterization of a Cretaceous black shale from Mamfe Basin, Cameroon. Petrol. Geosci., 12, $69-74$.

[18]. Espitalie J, Deroo G, Marquis F, (1985). “Rock-Eval pyrolysis and its application”. Inst. Fr. Pet. Preprint 33578, pp.72.

[19]. Guangyou Z, Zhengjun W, Jin S, (2013). Geochemical Characteristics of High quality Hydrocarbon Source Rocks in the Nanpu Sag of the Bohai Bay Basin, China. Oil Shale, 30(2), 117-135.

[20]. Hendrix MS, Brassell SC, Carroll AR, Graham SA, (1995). Sedimentology, organic geochemistry and petroleum potential of jurassic coal measures: Tarim, junggar and turpan basins, Northwest China. Amer. Assoc. Pet. Geol. Bull, 79, 929-959.

[21]. Hunt JM, (1979). Petroleum geochemistry and geology. Freeman, San Francisco.

[22]. Hunt JM (1996). Petroleum Geochemistry and Geology, second ed., W.H. Freeman and Company, New York.

[23]. Ikhane PR, Omosanya KO, Afolabi AO, (2011). Stratigraphy of Imobi, Southwestern Nigeria. Res. J. Earth Planet. Stud., 1(2), 33 45.

[24]. Illich HA, (1983). Pristane, phytane and lower molecular weight isoprenoid distributions in oils. Amer. Assoc. Petrol. Geol., Bull., $67,3385-393$

[25]. Kogbe CA, (1976). The Upper Cretaceous Abeokuta Formation of South Western Nigeria. Nigerian Field No. 4, December 1974

[26]. Longford FF, Blanc-Valleron MM, (1990). Interpreting Rock-Eval pyrolysis data using graphs of pyrolyzable hydrocarbons vs. total organic carbon Amer. Assoc. Petrol. Geol. Bull., 74(6), 799-804.

[27]. Meyer RF, Attanasi ED, Freeman PA, (2007). Heavy oil and natural bitumen resources in geological basins of the World. US Geological Survey Open-File Report 2007-1084. http://pubs.usgs.gov/of/2007/1084/OF2007-1084v1.pdf.

[28]. Murat RC, (1972). Stratigraphy and paleogeography of the Cretaceous and lower Tertiary in southern Nigeria. In: African Geology (Ed. By Dessauvagie, T.F.J. and Whiteman, A.J.), 251-266. Ibadan University press, Ibadan, Nigeria.

[29]. Nate H, (2008). The Oil Drum: Net Energy. Discussions about Energy and Our Future. Retrieved from http://www.theoildrum.com/node/3839 on 14 March, 2010.

[30]. Obaje NG, Wehner H, Scheeder G, Abubakar MB, Jauro A, (2004). Hydrocarbon prospectivity of Nigeria's inland basins: From the viewpoint of organic geochemistry and organic petrology. Amer. Assoc. Petrol. Geol. Bull., 87, 325-353. Odunaike RK, Laoye JA, Fasunwon OO, Ijeoma GC, Akinyemi LP, (2010). Geophysical mapping of the occurrence of shallow oil sands in Idiopopo at Okitipupa area South-western Nigeria. Afri. J. Env. Sci. Techn., 4(1), 034-044.

[31]. Peters KE, (1986). Guidelines for evaluating petroleum source rocks using programmed pyrolysis. Amer. Assoc. Petrol. Geol. Bull., 70, 318-329.

[32]. Peters KE, Moldowan JM, (1993). The Biomarker Guide: Interpreting Molecular Fossils

[33]. in Petroleum and Ancient Sediments. Prentice Hall Englewood Cliff, NJ. pp. 363.

[34]. Pingchang S, Zhaojun L, Reinhard G, Yinbo X, Rong L, Baoyi L, Qingtao M, Jinjun X (2013). Oil Yield and Bulk Geochemical Parameters of Oil Shales from the Songliao andHuadian Basins, China: A Grade Classification Approach, Oil Shale, 30(3), 402418.

[35]. Reyment RA, (1965). Aspects of Geology of Nigeria. University of Ibadan Press, Ibadan, Nigeria, pp. 133

[36]. Short KC, Stauble, AJ, (1967). Outline of geology of Niger Delta. Amer. Assoc. Petrol. Geol. Bull, 51, 761-779.

[37]. Sengüler I, Ayyildiz T, Onal Y, Onal M, (2008). Organic Geochemical Characterization and Mineralogic Properties of Mengen Oil Shale (Lutetian), Bolu-Turkey. Oil Shale, 25 (3), 359-375.

[38]. Syncrude ND, (2003). Production Reader. Retrieved from www.syncrude.com/production.html on 2 August, 2003

[39]. Tissot BP, Welte DH, (1984). Petroleum Formation and Occurrence, $2^{\text {nd }}$ Ed. Springer- Verlag, Berlin, Heidelberg, New York, Tokyo, pp. 699.

[40]. Tissot B, Durand B, Espitalie J, Combaz A, (1984). Influence of Nature and Diagenesis of Organic Matter in Formation of Petroleum. Amer. Assoc. Petrol. Geol. Bull., 58, 499-506.

[41]. Ukwuoma O, (1999). Study of composition of Nigerian Tar sand bitumen. Petrol. Sci. Techn., 17, 57-65.

[42]. Van Krevalen DW, (1961). Coal-typology, Chemistry, Physics, Constitution. Elsevier, Amsterdam, pp. 514.

[43]. Waples DW, (1985). Geochemistry in Petroleum Exploration. International Human Resources Development Corporation, Boston, pp. 232. 